\title{
PENGILUSTRASIAN CERITA RAKYAT SUKU MALIND
}

\author{
Oleh: Lejar Daniartana Hukubun \\ Institusi: Institut Seni Indonesia Yogyakarta
}

\begin{abstract}
ABSTRAK
Salah satu suku di Merauke adalah Malind, mereka memiliki cerita rakyat yang mengandung moral yang baik untuk kehidupan manusia. Namun sayangnya kebanyakan anak muda jaman sekarang sudah mulai melupakan sejarah yang seharusnya diingat sampai saat ini. Perancangan ini bertujuan untuk lebih memperkenalkan dan memberi edukasi kepada anakanak, agar mereka mengenal kebudayaan mereka melalui cerita rakyat sejak dini dan dapat mempraktekannya ke dalam ke hidupan mereka sehari-hari.

Metode yang digunakan dalam peracangan ini menggunakan analisis $5 \mathrm{w}$ 1h dan design thinking, hal ini digunakan untuk mendapatkan data secara valid. Pengumpulan data ini juga dilakukan dengan cara observasi, wawancara, dan dokumentasi. Selain itu, teori yang digunakan adalah teori Desain Komunikasi Visual. Manfaat yang dapat diperoleh dari teori adalah untuk mendapatkan jawaban dari masalah melalui strategi, pengamatan, refrensi serta pengalaman yang mereka alami.

Perancangan ini ditujukan untuk anak-anak usia 7-12 tahun. Perancangan ini menerapkan konsep komunikasi dan ungkapan daya kreatif agar dapat diterima oleh target audience. Agar dapat memecahkan masalah melalui pesan visual. Meracang buku ilustrasi cerita rakyat suku Malind merupakan solusi, agar kebudayaan Malind salah satunya cerita rakyat dapat dilestarikan. Sehingga anak-anak sejak dini mulai mengenal kebudayaan mereka, dengan begitu kebudayaan ini dapat dilestarikan.
\end{abstract}

Kata Kunci: Buku Ilustrasi, Cerita Rakyat Malind, Merauke

\section{ABSTRACT}

One of ethnic groupin Merauke is Malind, they have folk tales that contains of good moral ity for human life. But unfortunately many young people today have begun to left the history. This design aims to better way to introduce and educate children, so that they understand their education through folklore early on and can practice it into everyday life.

The method used in this design uses $5 \mathrm{w}$ 1h analysis and design thinking, this is to get data validity. Data collection is also done by work, interviews, and documentation. In addition, the theory used is the theory of Visual Communication Design. The benefits that can be obtained from theory are to learn from problems through strategies, observations, references and experiences they experience.

This design is purposed to children 7-12 years. This design applies the concept of communication and expression of creative power so that it can be accepted by the target audience. In order to solve problems through visual messages. Making a book that is shown by the Malind tribe folklore is a solution, so that the Malind service, one of which is folklore, can be preserved. Kids start to know them early, so this role can be preserved.

Keywords: Illustration Books, Malind Folklore, Merauke 


\section{PENDAHULUAN}

\section{A. Latar Belakang}

Indonesia memiliki keberagaman agama, suku, keindahan alam dan budaya yang tersebar dari Sabang sampai Merauke, hal ini menjadi kebanggan penduduknya sebagai warga negara Republik Indonesia. Sebagai warga negara yang cinta akan kekayaan bangsanya, maka menjadi sebuah kewajiban untuk menjaga dan memelihara keanekaragaman budaya bangsa Indonesia. Cerita rakyat merupakan salah satu warisan budaya yang penting untuk dilestarikan. Sebagai bagian dari hasil budaya, sebagai salah satu contohnya, cerita rakyat suku Malind menjadi alat untuk mengenalkan kearifan lokal daerah setempat, termasuk penerapan nilai-nilai sosial budaya yang berlaku di masyarakat. Manfaat cerita rakyat antara lain menyampaikan pesan moral bagi pembaca, terutama bagi anak-anak, agar memiliki budi pekerti yang baik dan dapat mengenal budaya lokal yang memiliki keunikan masing-masing daerah. Salah satu kebiasaan yang wajib ditanamkan kepada anak-anak adalah membaca. Sehingga diperlukan bahan bacaan yang berkualitas dan bermanfaat. Buku cerita rakyat menjadi salah satu pilihan bacaan yang bermanfaat, karena cerita rakyat mengandung norma-norma yang mempengaruhi perkembangan moral anak, melatih kecerdasan anak secara visual, emosional, kognitif/pengetahuan dan spiritual.

Cerita rakyat suku Malind, merupakan salah satu budaya lokal Indonesia, sehingga perlu kita cintai dan pelihara dengan baik. Hal ini diperkuat dengan pendapat Sumbo Tinarbuko (dalam Concept, 2015:25) bahwa untuk menjadi desainer grafis yang mengedepankan prinsip kelokalan dibutuhkan cara dengan melihat sebayak $25 \%$, mengamati $25 \%$, mempelajari $25 \%$ dan $25 \%$ mencintai dan bersahabat dengan budaya lokal Indonesia. Sehingga hasil perancangan buku cerita rakyat suku Malind dengan mengedepankan karakter bentuk wayang Papua diharapkan menjadi salah satu penanda visual atas eksistensi kebudayaan bangsa Indonesia dalam konteks peradaban modern.

Diperlukan media dalam menyampaikan sebuah pesan. Media tersebut adalah sebuah buku. Berdasarkan bentuknya, terdapat dua jenis buku yaitu buku cetak dan buku digital, pada dasarnya keduanya mempunyai kelebihan dan kekurangannya 
masing-masing dalam memerankan fungsinya sebagai media. Media digital mempunyai sifat praktis dalam kondisi tertentu, misalnya memudahkan untuk dibawa dalam perjalanan ke suatu tempat. Sedangkan kekurangannya yaitu dibutuhkan listrik dan bantuan media digital lainnya seperti laptop, sambungan internet, handphone. Menurut (Olsen, 1994) saat seseorang membaca buku cetak pembaca memindai bacaan untuk menemukan informasi tertentu, sekaligus mengingat informasinya dengan menandai letaknya dalam buku. Ingatan visual ini tidak terjadi pada kegiatan menelusuri bacaan digital (scrolling up, scrolling down). Teks digital umumnya dibaca secara parsial, sehingga pembaca tidak membacanya sebagai satu kesatuan ide secara utuh.

Konten digital lebih digemari karena menawarkan jalan pintas untuk mengakses informasi, dan keunggulan multimodalitasnya. Teks, gambar atau elemen visual lainnya, suara, dan fitur interaktif sebagai unsur-unsur yang melengkapi teks digital. Paket ini lengkap untuk mengakomodasi bagi pembaca berkebutuhan khusus atau pembaca dengan gaya belajar visual, auditori, dan kinestetik. Sehingga kebutuhan kedua media cetak maupun digital saling melengkapi. Media digital lebih sesuai untuk kebutuhan instan, sedangkan media cetak membantu memahami informasi secara menyeluruh (Dewayani, 2017:36).

Buku dalam perancangan ini dibuat dengan menggunakan media cetak, karena dapat memberikan durasi waktu yang panjang dibandingkan dengan media digital. Digunakannya media digital, salah satunya dapat bermanfaat untuk menyimpan data melalui format $J P E G$, untuk beberapa tahun ke depan apakah format tersebut masih bisa bertahan dan apakah gambar tersebut bisa dibuka tanpa ada gangguan? Sehingga dapat dikatakan media cetak salah satunya buku, menjadi salah satu solusi sebagai media cetak yang memiliki sifat tak lengkang oleh waktu. Manfaat lain dari media cetak adalah perancangan yang menekankan pada perihal arsip dan waktu, diwujudkan melalui ilustrasi buku. Walapun perkembangan jaman dan teknologi semakin maju dalam menyampaikan pesan komunikasi visual, namun buku cetak menjadi salah satu solusi yang masih relevan hingga saat ini.

Salah satu cerita rakyat yang diangkat dalam perancangan buku ilustrasi ini adalah cerita rakyat suku Malind. Menurut Samkakai (2013), sebelum terjadi 
pemekaran kabupaten, suku Malind \& Suku Asmat berada dalam satu daerah atau satu kabupaten Merauke, namun setelah pemekaran suku Malind tetap berada di kabupaten Merauke dan Suku Asmat membentuk kabupaten yang baru yaitu kabupaten Asmat, keduanya berada dalam satu propinsi yaitu propinsi Papua. Makanan pokok masyarakat Malind adalah sagu, dengan sistem mata pencaharian hidup tradisional terutama dalam cara berburu dan menangkap ikan. Penangkapan ikan dilakukan dengan cara menjaring, menombak, dan memanah, sedangkan pekerjaan masyarakat Malind yang lain adalah pegawai negeri, ABRI, wiraswasta, dan petani.

Berdasarkan informasi dari tokoh-tokoh masyarakat Papua yang berdomisili di Yogyakarta, cerita rakyat suku Malind ini masih masuk dalam budaya lisan dan belum ada yang mendokumentasikan dalam bentuk buku atau media lainnya, sehingga penyebarannya, menjadi sangat terbatas. Dijelaskan pula bahwa hasil budaya lokal ini hampir punah karena diterjang oleh budaya lainnya ataupun ceritacerita dari luar etnis ini. Sedangkan penggalian data melalui searching google dengan kata kunci cerita rakyat suku Malind, hanya terdapat dari kurang dari 15 artikel yang terkait dengan objek, dan dari segi isi materi lebih banyak masih bersifat umum. Sehingga diperlukan proses sosialisasi melalui media, dalam hal ini berupa buku, karena cerita rakyat suku Malind sebagai salah satu aset budaya yang memiliki nilai keunikan yang berbeda dengan budaya lainnya.

Fakta menunjukkan bahwa cerita rakyat yang ada sudah menjadi legenda, mitos, fabel ataupun sejenisnya, tetapi hal itu sifatnya masih menjadi budaya lisan yang penyampaiannya harus diceriterakan oleh orang tua pada anak-anak. Sementara yang terjadi sampai saat ini, banyak anak-anak yang lebih menyukai cerita-cerita yang disampaikan melalui media iklan, televisi dan perangkat atau alat-alat kecerdasan buatan, seperti handphone atau bentuk gadget lainnya, dengan demikian pesan yang akan disampaikan cepat hilang, sehingga diperlukan buku sebagai media untuk mewadahi cerita rakyat agar dapat memiliki fungsi sepanjang waktu. Hal ini menjadi kebutuhan masyarakat. Untuk itu, sebuah buku cerita rakyat dimunculkan agar dapat menjadi inspirasi masyarakat pembaca. Salah satu bentuk ilustrasi cerita rakyat yang akan dirancang dengan menggunakan karakter bentuk wayang Papua. 
Berdasarkan survei yang dilakukan melalui angket yang diberikan kepada 85 (lima puluh) orang Papua termasuk narasumber lain yang ada di Yogyakarta, mereka sebagian besar menempuh pendidikan di APMD, UST, PGRI, UGM Yogyakarta; menyatakan bahwa terdapat $93 \%$ responden setuju bahwa cerita rakyat suku Malind dibuat menjadi sebuah buku. Mengacu pada data kuantitatif yang diperoleh dari hasil penyebaran angket dan hasil survey melalui wawancara dengan tokoh-tokoh masyarakat Papua, maka permasalahannya adalah bagaimana merancang cerita rakyat suku Malind ke dalam bentuk buku dengan ilustrasi wayang Papua. Media wayang dihadirkan untuk mengenalkan salah satu hasil budaya Jawa kepada anak - anak. Ilustrasi wayang Papua merupakan perpaduan antara produk budaya Jawa dan Papua. Hal ini sebagai penggalian gagasan/ide yang dapat mengajarkan kepada anak-anak bahwa kreativitas dapat bersumber dari mana saja, dan hasilnya bisa dipadukan menjadikan suatu hal yang baru. Penggabungan bentuk karakter ini diharapkan dapat menginspirasi anak-anak dalam berfikir kreatif dalam berkarya seni dan bisa diaplikasikan ke dalam aspek kehidupan lainnya, sehingga mereka dapat menciptakan hal yang baru, untuk memecahkan sebuah masalah.

Penyampaian isi dan pesan dari sebuah cerita, akan dihadirkan sebuah karakter yang unik, khas dan spesifik yaitu berupa ilustrasi wayang Papua. Ilustrasi akan berfungsi untuk memperjelas isi cerita tersebut. Fungsi utama ilustrasi adalah untuk menghias dan mendukung guna membantu atau memperjelas suatu objek, dalam hal ini adalah cerita rakyat suku Malind. Umumnya ilustrasi berupa gambar, karena akan lebih mudah untuk dipahami sifat pembacaannya dari pada tulisan. Meskipun demikian tulisan bisa difungsikan sebagai ilustrasi dalam bentuk gambar (tipografi), dalam hal ini 'kata' menjadi unsur verbal yang divisualkan (Koskow, 2013:128).

Perancangan ilustrasi wayang ini terjadi sebagai hasil modifikasi sesuatu yang sudah ada menjadi konsep yang baru, menghubung - kaitkan segala sesuatu yang tadinya tak terhubung. Marianto (2017:1), dengan pengertian lain terdapat dua konsep lama yang dikombinasikan menjadi suatu konsep baru. (Semiawan dalam Iswantara 2017:7) konsep lama disini adalah wayang Jawa yang dikombinasikan dengan ornamen Papua. 


\section{PEMBAHASAN}

\section{A. Metode Perancangan}

Perancangan ini menggunakan metode design thinking didalam metode tersebut menggunakan tahapan membuat karya, langkah-langkah tersebut memiliki pembahasan sebuah karya, tahapan dan langkah memiliki pembahasan yang berbeda. Namun sesuai dengan perancangan sebuah karya dari awal hingga final.

Dari pembahasan di atas dapat disimpulkan bahwa langkah yang digunakan menggunakan emphatize, define, ideate, prototype, testing. Tahapan ini selalu berkaitan dari awal hingga akhir untuk mendapatkan latar belakang masalah, ide, cara penyelesain, dan mengetahui jawaban yang tepat dari latar belakang masalah.

\section{Data Primer}

Data primer merupakan data asli yang di kumpulkan periset untuk menjawab masalah risetnya secara khusus, data tersebut diperoleh secara langsung dari sumbernya ataupun dari objek penelitian, baik melalui media kuisioner, wawancara, ataupun pendekatan melalui observasi (Istijanto, 2005:45). Data primer meliputi :

- Observasi

Observasi dilakukan dengan cara terjun kelapangan dan mengamati secara langsung keadaan yang sedang terjadi rumah - rumah adat orang Malind. Selain itu pengamatan juga dilakukan dengan melihat rumah orang Malind yang saat ini digunakan bagaimana bentuk dan jenis bangunannya. Keadaan alam di alam juga diamati bagaimana keadaan tanahnya, tumbuhan tumbuhan yang sering ditanam, bagaimana cara bersosialisasi dengan sesamanya dan yang lainnya.

Rumah adat di suku Malind sekarang beralih fungsinya untuk tempat berdoa, dalam adat agama katholik sering disebut dengan rumah adorasi. Sedangkan rumah yang ditempati oleh orang Malind berbentuk rumah biasa yang terbuat dari batu bata dan jendela pada umumnya. Mereka membuat rumah dengan membuat toliet terpisah dari rumah. Terkadang mereka juga memelihara babi untuk keperluan dan kebutuhan hidup mereka, ada dua jenis babi yang mereka pelihara yang pertama babi hutan dan babi ternak 
yang bewarna merah muda. Masyarakat suku Malind sangat menjaga kehidupan adat mereka sehingga tidak terlalu mau membaur dengan orang yang berada diperkotaan. Hal itu bertujuan agar adat dan budaya Malind terus berlangsung dengan baik tanpa terganggu dengan budaya perkotaan. Salah satu kebudayaan dari Malind adalah cerita rakyat yang kini mulai dilupakan oleh penduduk sekitar, sehingga melalui perancangan ini sebagai langkah untuk mengingat kembali kebudayaan mereka.

\section{- Wawancara}

Wawancara dilakukan kepada beberapa narasumber yaitu pengusaha kerajinan Merauke, para ketua adat Merauke, masyarakat Malind, ketua adat Malind, Penulis buku cerita rakyat Malind, kepala dinas kebudayaan olah raga dan pariwisata, beserta narasumber yang lainnya. Dari sekian banyak orang yang dimintai pendapat, diwakilkan beberapa narasumber yang dapat disampaikan diantaranya adalah Jhon Gluba Gepze mantan gubernur kota Merauke, Alyoisius Wemba Mahuze seorang penduduk asli Malind Pantai, Pastor Andreas Fanombi, Daud Hollonger pecinta budaya Papua, Isaias J Ndiken penulis buku cerita rakyat Malind, Panca pengusaha kerajinan Papua di Merauke, Sam Akbar dosen Musamus Merauke. Beberapa contoh pertanyaan yang akan digunakan antara lain tentang kebudayaan Merauke, cerita rakyat, dan ilustrasi wayang Papua.

\section{- Dokumentasi}

Dokumentasi dilakukan dengan teknik mengambil gambar atau foto sebagai contoh media yang membantu untuk membuat perancangan ilustrasi buku ini. Dilakukan di beberapa tempat yang dianggap sesuai dengan kebutuhan perancangan yang akan dibuat yaitu rumah orang Malind, Orang Malind, rumah adat, tumbuhan dan kondisi alam kampung yang ada di Malind seperti, tanah, sungai, rawa, pepohonan, ikan, kangguru, anjing, rusa dan yang lainnya. 


\section{Data Sekunder}

Data sekunder didapatkan dengan menggunakan metode kepustakaan, yaitu dengan teknik pengumpulan data, dengan mengadakan studi pengkajian terhadap buku, literatur, catatan, laporan yang ada hubungannya dengan masalah yang dipecahkan. Melalui metode ini dilakukan penelitian dengan cara mempelajari dan membaca literatur yang berhubungan dengan masalah dan karya sejenis. Contohnya seperti jurnal, tesis, dan buku yang menjadi objek penelitian. Semua referensi tersebut berguna untuk menyampaikan pesan kepada target audience tentang cerita rakyat suku Malind. Berikut contoh Tesis, Jurnal dan bukunya:

1. Perancangan Buku Ilustrasi Surabaya Heritage, Tesis yang ditulis oleh Satrya Dirgantara, Institut Seni Indonesia, Yogyakarta 2015.

2. Perancangan Buku Ilustrasi Surabaya Heritage, Jurnal yang ditulis oleh Satrya Dirgantara, Institut Seni Indonesia, Yogyakarta 2015.

3. Maerauke, Tanah Malind Suatu Pendekatan Pemetaan Budaya Suku Bangsa, Buku tentang suku Malind tahun 2013 yang dibuat oleh Frumensius Obe Samkakai, S.Sos, Drs. Daud Hollenger,M.Pd, dan Isayas Yanggel Ndiken, S.Sn.

4. Art \& Life Force in a Quantum Perspective, Buku tentang seni dan daya hidup tahun 2017 yang dibuat oleh Prof. Martinus Dwi Marianto, MFA,Ph.D

Selain buku-buku tersebut, buku ilustrasi seperti Good Good Father buah karya dari Chris Tomlin yang diterbitkan tahun 2016. Buku ini mempunyai manfaat sebagai acuan tata letak, layout dan media. Sehingga dapat menyampaikan pesan visual terhadap target audience yaitu anak-anak.

\section{Mind Mapping}

Pada tahapan ini adalah hasil dari pengumpulan data verbal dan visual untuk menemukan permasalahan yang terjadi. Tujuan Mind Mapping ini adalah untuk memecahkan masalah serta mencari solusi agar permasalahan dan fenomena yang ditemukan dapat dipecahkan menggunakan disiplin ilmu Desain Komunikasi Visual. Setelah melakukan tahap ini hal yang diperoleh adalah kebutuhan akan informasi tentang sejarah kebudayaan Malind dan cerita rakyatnya untuk target audience. 


\section{Analisis}

Analisis digunakan untuk memahami kebudayaan suku Malind dan cerita rakyatnya. Analisis dalam perancangan ini menggunakan $5 \mathrm{~W}+1 \mathrm{H}$, dengan analisis $5 \mathrm{~W}+1 \mathrm{H}$ (what, where, when, why, who, dan how), sehingga bermanfaat untuk mengetahui secara detail mengenai kebudayaan Malind. Hasil dari analisis ini menjadi acuan dalam menentukan strategi visual yang tepat.

\section{a. What (apa): Apa masalahnya?}

Orang Malind merupakan suku asli di Merauke, meskipun banyak pendatang banyak orang Malind yang tetap tinggal di Merauke namun terpisah dari masyarakat perkotaan dan tidak sedikit orang ingin mengetahui bagaimana kebudayaan suku asli kota rusa ini. Perpustakaan kota dan kampus di Merauke tidak banyak memiliki data yang cukup mengenai suku ini. Hanya di gereja katedral yang memiliki cukup banyak informasi tertulis namun kebanyakan masih wujud bahasa Belanda. Hal tersebut menjadi kesulitan tersendiri jika orang Indonesia ingin mengenal suku Malind lebih dalam. Generasi muda dari kota ini sudah banyak yang tidak mengingat lagi kebudayaan dan adat mereka. Membuat ilustrasi cerita rakyat suku Malind adalah salah satu upaya untuk mengingatkan kebudayaan mereka lewat cerita rakyat. Mengingat buku tentang suku Malind masih sedikit, jadi pengetahuan informasi tentang suku Malind di Mearuke masih kurang.

\section{b. Who (siapa): Siapa target audience yang akan dituju?}

Sasaran utama pada buku ini adalah anak-anak sekolah dasar, karena mulai dari kecil mereka akan mengenal dan memahami cerita rakyat yang akan ditawarkan, makna moral yang baik dari cerita rakyat ini akan dipahami dengan baik oleh mereka, sehingga mereka mampu untuk menerapkan prinsip kehidupan yang baik dalam hidup mereka sejak dini, melalui cerita rakyat. Dari penetapan segmentasi target audience maka akan dijabarkan secara detail demografis, geografis dan psikografis dari target audience, sebagai berikut:

\section{- Demografis}

Jenis Kelamin : Laki - laki dan Perempuan

Usia : 7 tahun sampai 12 tahun 
Pendidikan : Sekolah Dasar

- Geografis

Kota-kota besar di Papua khususnya kota Merauke tempat asal suku Malind.

\section{- Psikografis}

Menyukai ilustrasi dan memiliki rasa keingintahuan yang tinggi, aktif, suka membaca buku dan mengunjungi tempat - tempat hiburan bersejarah seperti kebudayaan suku Malind.

c. Where (dimana): Dimana perancangan ini disampaikan?

Penyampaian pesan perancanggan dilakukan dan disampaikan di kota Merauke, Papua, Jawa dan sekitarnya karena perancangan ini hanya berfokus utama kepada masyarakat Merauke dan Jawa. Ilustrasi yang akan ditampilkan menggunakan karater wayang Papua sehingga orang jawa bisa lebih mudah menerima budaya tersebut. Untuk orang Merauke mereka mendapatkan inspirasi hal yang baru lewat karakter wayang Papua.

d. When (kapan): Kapan perancangan ini disampaikan?

Perancangan ini disampaikan ketika ulang tahun kota Merauke tanggal 12 Febuari 2018, pada hari tersebut banyak kegiatan pengenalan lebih dalam tentang kota Merauke, tak hanya sejarah tetapi juga makanan tradisional, permainan tradisonal, dan pesta adatnya. Hari tersebut adalah hari yang tepat untuk menyampaikan perancangan ini, karena banyak warga dan anak-anak yang ikut serta dalam perayaan sebagai masyarakat yang mengenal dan mencintai kota Merauke.

e. Why (kenapa): Kenapa masalah ini terjadi?

Anak-anak dan generasi muda banyak yang kurang mengetahui sejarah dan kebudayaan Malind yang berada di Merauke. Buku - buku sejarah yang membahas tentang kebudayaan tersebut juga masih sangat jarang ditemukan, sehingga mereka yang ingin mengetahui kebudayaan tersebut akan terasa sulit. Untuk itu melalui ilustrasi buku cerita rakyat suku Malind dapat menjadi media edukasi yang memberikan ilmu tentang sejarah kebudayaan suku Malind yang dimiliki kota Merauke. 
f. How (bagaimana): Bagaimana mengatasi masalah dan memberi solusi?

Selama ini pada pelajaran muatan local di sekolah dasar belum terdapat pelajaran kebudayaan Malind. Sehingga anak-anak belum mendapatkan pengenalan kebudayaan Malind lewat sekolah mereka, jadi perancangan ilustrasi buku cerita rakyat suku Malind ini memberikan pintu pengenalan lewat karya sastra dan seni rupa dalam wujud ilustrasi. Harapannya mereka tertarik untuk membaca dan memahami maksud yang ingin disampaikan dari cerita tersebut, sehingga pesan moral yang ada dalam cerita dapat diaplikasikan dalam kehidupan mereka, serta kebudayaan Malind dapat dikenalkan sejak dini.

\section{B. Konsep Perancangan}

Konsep dasar perancangan merupakan suatu gagasan/pemikiran awal atau pedoman untuk membuat sebuah penciptaan, sehingga dalam pembuatan perancangan ini mempunyai arah dan tujuan yang jelas dalam menyampaikan informasi kepada target audience. Dalam perancangan ini perlu sebuah konsep kreatif program komunikasi. Program komunikasi tersebut tidak hanya sebagai program perancangan saja tapi juga bertujuan untuk mengajak para target audience lebih mengenal kebudayaan Malind lewat cerita rakyat. Program komunikasi tersebut diharapkan dapat menarik sebanyak mungkin para anak - anak lain, agar kebudayaan Malind melalui cerita rakyat dapat tersebar luas. Ide utama dari perancangan ini diambil dari kesimpulan analisis yang telah diteliti yaitu dengan mengajak audience untuk mengenal dan memahami cerita rakyat Malind. Salah satu solusi yang akan dilakukan adalah dengan membuat perancangan buku ilustrasi cerita rakyat suku Malind.

\section{Pemilihan Bentuk Pesan Verbal (Keyword)}

Kata kunci dalam perancangan ini adalah "cerita rakyat suku Malind". Maksud dari kata tersebut adalah Malind juga mempunyai cerita rakyat sebagai salah satu akar budaya kebudayaan yang ada di Merauke.

\section{Pemilihan Bentuk Pesan Visual}

Dalam memilih pesan visual pada perancangan ini adalah gaya visual dekoratif dimana tema tersebut memiliki gambaran visual yang simple dan mudah dipahami. 
Ada empat hal yang mendasari pemilihan bentuk visual, yaitu ilustrasi gaya desain, warna, tipografi dan layout:

- Ilustrasi

Perancangan ini menggunakan ilustrasi dekoratif, yang digunakan untuk semua objek yang ada pada visualisasi yang akan ditampilkan. Ilustrasi dekoratif digunakan karena mempunyai sifat sederhana dan menggunakan sedikit warna pada setiap gambarnya dan banyak digemari oleh anak-anak.

- Warna

Warna yang digunakan untuk perancangan ini adalah warna sekunder.

Warna ini disesuaikan dengan konsep perancangan buku ilustrasi pada sukusuku atribut orang Malind. Warna ini juga disesuaikan dengan keadaan orang Malind serta keadaan alam dan lingkungan sesungguhnya.

- Tipografi

Tipografi yang digunakan untuk perancangan ini sebagai unsur grafis adalah dengan tipografi yang memiliki legibility, clarity, visibility, dan readability, sehingga informasi yang ingin disampaikan dalam perancangan ini dapat tersampaikan denga tepat. Ukuran yang terdapat ilustrasi ini disesuaikan agar huruf yang digunakan bisa terbaca dengan jelas oleh target audience selain itu pemilihan huruf disesuaikan dengan karakter dari ilustrasi dekoratif, supaya informasi yang disampaikan dalam buku bisa terbaca dan mudah dipahami.

- Layout

Penggunaan layout yang digunakan dalam perancangan ini menggunakan trend Axial Layout, ciri dari layout ini adalah mempunyai tampilan visual yang kuat di tengah halaman dengan tampilan element pendukung terletak disekeliling gambar utama biasanya berupa gambar dan tulisan yang berhubungan dengan tampilan di tengah halaman sebagai pusatnya. Layout bisa terganggu dengan huruf, ornamen, atau hiasan yang kurang sesuai, sehingga perlu teori dalam melayout. Semua bagian layout harus menyatu satu dengan yang lainnya, sehingga membentuk keseluruhan layout. 


\section{Pemilihan Media}

Terdapat dua pilihan media utama dan media pendukung, yang pertama adalah media utama pada perancangan ini menggunakan buku ilustrasi yang berfokus pada target audience dan bertujuan untuk menyampaikan pesan utama dari bentuk verbal kedalam bentuk visual. Selain itu dilengkapi dengan media yang kedua yaitu media pendukung sebagai reminder atau pengingat agar target audience tidak melupakan media utama yaitu buku ilustrasi. Media pendukung ini dapat berwujud totebag, pembatas buku, poster dan topi. Dari hasil analisis media tersebut yang sangat cocok dengan kebutuhan dunia anak - anak sekolah dasar.

\section{Aplikasi Karya:}

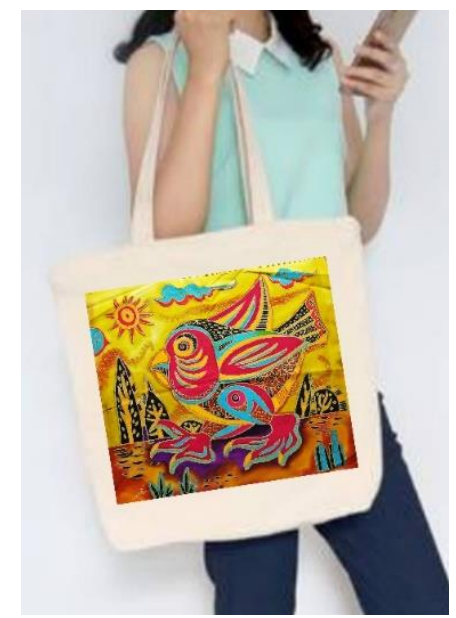

Gambar 1. Aplikasi karya pada totebag

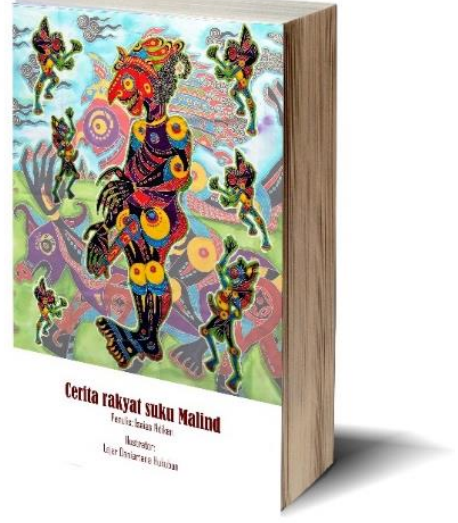

Gambar 2. Aplikasi karya pada buku

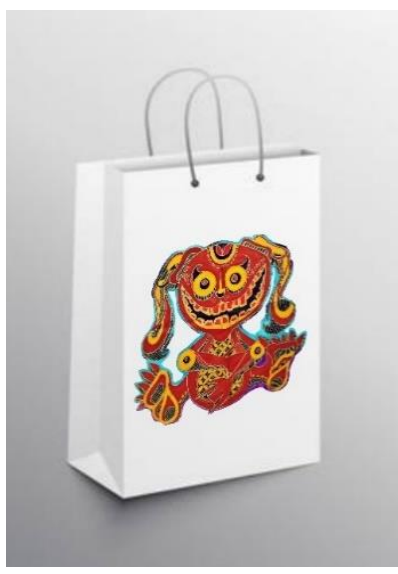

Gambar 3. Aplikasi karya pada tas kertas

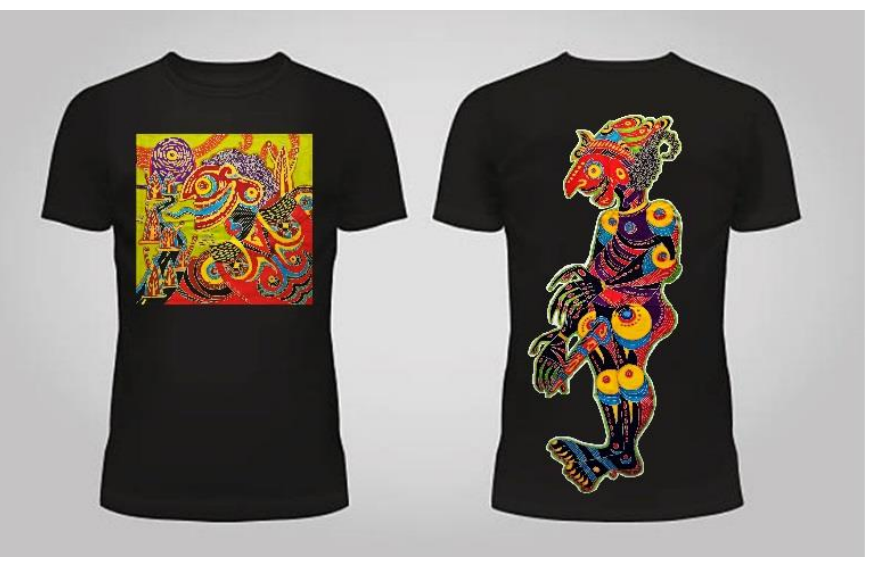

Gambar 4. Aplikasi karya pada kaos 


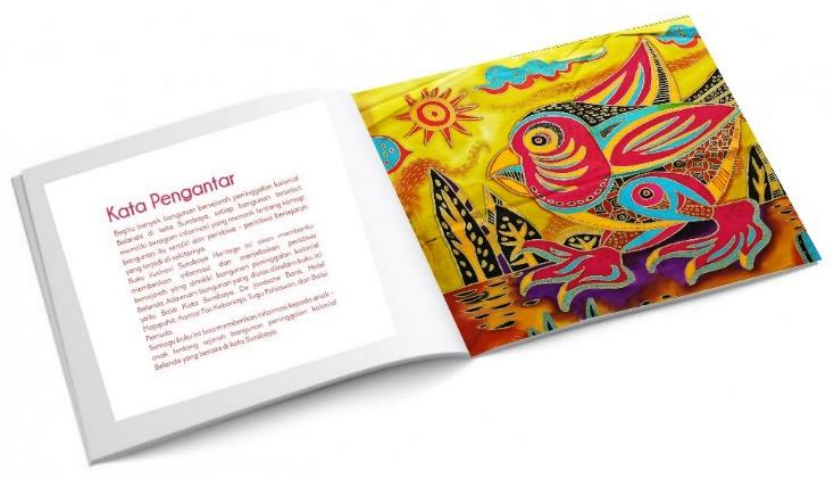

Gambar 5. Ilustrasi di dalam buku

\section{KESIMPULAN:}

Semua sub suku Malind yang ada di Merauke tidak seluruhnya mampu dijangkau dikarenakan jarak, waktu dan dana yang kurang mendukung. Beberapa tokoh adat dan masyarakat penduduk Malind asli masih kuat mempertahankan kebudayaannya agar tidak terganggu dengan kebudayaan luar. Suku ini masih sangat tertutup, untuk bisa mengenal dan akrab dengan mereka bukanlah hal yang mudah. Proses empaty dari metode design thinking sangat dipertaruhkan bagaimana kita bisa masuk dalam pergaulan mereka sehingga timbul keakraban. Nama marga juga sangat diperhitungkan, apakah marga kita mempunyai jasa yang baik atau sebaliknya. Sehingga kita bisa memperoleh data yang kita cari.

Generasi muda di perkotaan mulai lupa dengan kebudayaannya, salah satunya dengan asal usul cerita rakyat mereka banyak yang belum mengerti, begitu pula dengan berbagai kebudayaan lain yang mungkin mereka kurang pahami. Perancangan ini bertujuan untuk membangkitkan dan melestarikan kebudayaan Malind di kota Merauke lewat cerita rakyat yang dilengkapi dengan ilustrasi. Media yang digunakan dengan karakter wayang Papua agar budaya Malind dapat dengan mudah diterima oleh masyarakat Jawa dan luar Papua. 


\section{DAFTAR PUSTAKA}

\section{Buku}

Ambrose, Gavin., dan Paul Harris. (2010), Design Thikning, AVA Publishing SA, Switzerland

Budiman, Kris. (2011), Semiotika Visual, Konsep, Isu, dan Problem Ikonisitas, Jallasutra, Yogyakarta.

Dirgantara, Satrya. (2015), Perancangan Buku Ilustrasi Surabaya Heritage, Tesis, Institut Seni Indonesia, Yogyakarta.

Dewayani, Sofie. (2017), Menghidupkan Literasi di Ruang Kelas, Kanisius, Yogyakarta.

Gamgenora, Fr Ferry, S.Psi. (2010), Apa Sebab Anak Bisa Nakal, Bajawa Press, Yogyakarta.

Gamgenora, Fr Ferry, S.Psi. (2014), Psikologi Cinta Mengenal Cinta Palsu, Bajawa Press, Yogyakarta.

Gamgenora, Fr Ferry, S.Psi. (2014), Psikologi Belajar Apa Sebab Habis Belajar Lalu Lupa, Bajawa Press, Yogyakarta.

Hukubun, Daniartana Lejar. (2015), Perancangan Ilustrasi dengan Karakter Bercorak dan Berteknik Batik Untuk Novel Republik Rimba Karya Ryan Sugiarto, Mandiri, Yogyakarta.

Hukubun, Penias. (56 th.), tokok Kabupaten Merauke, wawancara tanggal 20 Juli 2018, di Wirobrajan, Yogyakarta.

Ihromi, T.O. (1980), Pokok - Pokok Antropologi Budaya, Penerbit PT Gramedia, Jakarta.

Iswantara Nur Dr. M. Hum (2017), Kreativitas Sejarah, Teori, dan Perkembangan, Gigih Pustaka Mandiri. Yogyakarta.

Iyan., Wb. (2007), Anatomi Buku, Kolbu, Bandung.

Istijanto, (2005). Riset Sumber Daya Manusia, Jakrta: PT. Gramedia Pustaka

Kadiasti, Ristia. (2015), Perancangan Buku Ilustrasi Sejarah Stasiun Samarang, Tesis, Institut Seni Indonesia Yogyakarta.

Kompas, Laporan Jurnalistik. (2009), Ekspedisi Tanah Papua, Kompas, Jakarta. 
Koskow, (2009), Merupa Buku, Lkis, Yogyakarta

Kamus Besar Bahasa Indonesia, (2001), Balai Pustaka, Jakarta.

Marianto, Dwi M. (2017), Art \& Life Force in a Quantum Perspective, Scritto, Yogyakarta

Marahimin, Ismail. Hadits, Fawzia Aswin. (2012), Kreatif Menulis Cerita Anak, Nuansa, Bandung.

Mangunwijaya, Pr. YB. (1998), Gereja Diaspora, Kanisius, Yogyakarta.

Maharsi, Indira, M.Sn. (2016), Ilustrasi, ISI, Yogyakarta.

Peday, Ayub. Drs.MM, Kanggam, Willibrordus. S.Sos, Mahuze .M Yoseph, SE.Par, Ronggo D. Alexius,S.Si. (2013), Kumpulan Cerita Rakyat Daerah Malind, Dinas Kebudayaan dan Pariwisata Kabupaten Merauke, Merauke.

Permendikbud_Tahun2016_Nomor024_Lampiran_30 (1)

Samkakai, Frumensius Obe. Hollenger, Daud. Ndiken, Isayas Yanggel. (2013), Tanah Malind Suatu Pendekatan Pemetaan Budaya Suku Bangsa, Dinas Kebudayaan dan Pariwisata Kabupaten, Merauke.

Sarumpaet, Toha.K.Riris.(2016), Pedoman Penelitian Sastra Anak, Obor, Yogyakarta.

Tinarbuko, Sumbo. (2016), DEKAVE Desain Komunikasi Visual Penanda Zaman, Caps, Yogyakarta.

Tinarbuko, Sumbo. (2009), Semiotika Komunikasi Visual, Caps, Yogyakarta.

Titik. WS., Sarumpaet Toha, Riris K. Basino P.1, Titis, Layun Rampan, Sumardi, Korrie. Marahimin, Ismail. Hadits, Fawzia Aswin. (2012), Kreatif Menulis Cerita Anak, Nuansa. Bandung.

\section{Wawancara}

Bendy. (36 th.), Galio Maniani. (42 th.), dan Ferry Gamgenora. (46 th.), warga Papua di Yogyakarta, wawancara tanggal 22 Juli 2018, di Asrama Kamasan, Yogyakarta.

Hukubun, Penias. (56 th.), tokoh Kabupaten Merauke, wawancara tanggal 20 Juli 2018, di Wirobrajan, Yogyakarta.

Gepze, Jhon Gluba. (65 th), mantan bupati kabupaten Merauke, wawancara tanggal 10 September 2018, di Merauke. 
Ndiken, Isaias $\mathbf{J}$ (55 th), kepala dinas kebudayaan Merauke, penulis cerita rakyat suku Malind, wawancara tanggal 14 September 2018, di Merauke.

Pastor Fanombi, Andreas (54 th), pastor kepala suku Malind di Kumbe, wawancara tanggal 15 September 2018, di Merauke.

Mahuze, Alyoisius Wemba (70 th), salah satu warga suku Malind marga Mahuze, wawancara tanggal 9 Oktober 2018, di Merauke.

Hollonger, Daud (54 th), kepala dinas Kebudayaan \& Pariwisata Merauke, wawancara tanggal 12 September 2018, di Merauke.

Panca, (45 th ), pengusaha kerajinan Istana Merauke, wawancara 12 September 2018, di Merauke.

Akbar, Sam (57 th) dosen kebudayaan Musamus Merauke, wawancara 12 September 2018, di Merauke.

\section{Internet}

https://anzdoc.com/perancangan-komunikasi-visual-buku-interaktif-cerita-rakyat.html

https://www.canva.com/id_id/belajar/desain-sampul-buku/

http://pembuatanlogo.com/tujuan-ilustrasi-dalam-desain-komunikasi-visual/

http://www.indonesiadesign.com/art-design/art-lessons-from-the-renowned-rita-

widagdo/

https://kumalahayati16.wordpress.com/2015/04/07/kelebihan-dan-kekurangan-bukucetak/

http://repositori.perpustakaan.kemdikbud.go.id/ Papua\%20 Terpilih.pdf

https://sis.binus.ac.id/2017/12/18/design-thinking-2/

http://www.sumberpengertian.co/pengertian-diaspora-menurut-para-ahli

jurnal-s1.fsrd.itb.ac.id/index.php/viscom/article/download 